Article

\title{
The Behaviour of Mixtures of Sodium Iso-Butyl Xanthate and Sodium Di-Ethyl Dithiophosphate during the Flotation of a Cu-Ni-Pt Ore in Degrading Water Quality
}

\author{
Malibongwe S. Manono ${ }^{1, *}$, Katlego Matibidi ${ }^{1,2}$, Iyiola O. Otunniyi ${ }^{2}$, \\ Catherine K. Thubakgale ${ }^{2} \mathbb{D}$, Kirsten C. Corin ${ }^{1} \mathbb{( D}$ and Jenny G. Wiese ${ }^{1}$ \\ 1 Centre for Minerals Research, Department of Chemical Engineering, University of Cape Town, Private Bag \\ X3, Rondebosch 7701, South Africa; katlego.m.matibidi@gmail.com (K.M.); kirsten.corin@uct.ac.za (K.C.C.); \\ jenny.wiese@uct.ac.za (J.G.W.) \\ 2 Department of Metallurgical Engineering, Vaal University of Technology, Private Bag X021, Vanderbijlpark \\ 1911, South Africa; iyiolao@vut.ac.za (I.O.O.); kentset@vut.ac.za (C.K.T.) \\ * Correspondence: malibongwe.manono@uct.ac.za; Tel.: +27-21-650-1679
}

Received: 3 December 2019; Accepted: 14 January 2020; Published: 31 January 2020

\begin{abstract}
The use of mixtures of thiol collectors is reportedly beneficial in sulfide flotation. This is becoming standard practice for many concentrators, but process water recirculation and re-use in flotation circuits may compromise the behaviour of such mixtures owing to changes in physicochemical interactions occurring in the pulp phase as a result of water quality variations. It is expected that changes in the pulp chemistry would in turn affect both the pulp and froth phase phenomena, thereby affecting flotation performance. Thus, this study considers mixtures of thiol collectors, sodium iso-butyl xanthate (SIBX), and sodium di-ethyl dithiophosphate (SEDTP) in degrading water quality. Bench-scale flotation tests were conducted on various molar ratios of the selected thiol collectors under different ionic strengths $\left(0.0242 \mathrm{~mol} \cdot \mathrm{dm}^{-3}\right.$ and $\left.0.1212 \mathrm{~mol} \cdot \mathrm{dm}^{-3}\right)$ of synthetic plant water. Increasing the ionic strength of synthetic plant water and SEDTP molar ratio resulted in an increase in water, solids, $\mathrm{Cu}$, and $\mathrm{Ni}$ recoveries. $\mathrm{Cu}-\mathrm{Ni}$ grades decreased in increasing SEDTP molar ratios. The highest $\mathrm{Cu}-\mathrm{Ni}$ grades were obtained in degrading water quality. The increase in water and solids recoveries in increasing SEDTP and ionic strength of plant water is attributed to an increase in froth stability. It can be concluded that the increase in the ionic strength of plant water increased water recoveries and therefore froth stability in parallel with SEDTP's froth stabilizing effect, thus suggesting an additive interaction on the froth stabilisation effect seen.
\end{abstract}

Keywords: flotation; froth stability; ionic strength; thiol collectors; water quality

\section{Introduction}

The mining industry is faced with a challenge of developing innovative, economical, and environmentally safe methods by which the base metal sulfides and platinum group minerals contained in value bearing ore bodies can be extracted and separated from non-sulfide gangue. Current approaches have sought to complement or improve existing techniques. One such existing technique is froth flotation. This technique exploits the differences in the physico-chemical properties of minerals present in the ore so as to separate valuable minerals from gangue. It is, however, acknowledged that this technique is complex in that it has to be carefully controlled so as to selectively float the value-bearing sulfides from the non-sulfide gangue minerals. The management and control of this process requires an in-depth understanding and knowledge of the effects that hydrodynamic and 
chemical changes of the environment may have on the success of the process. As such, the chemistry of the pulp environment is controlled through the addition of chemical reagents to ensure that the necessary selectivity is achieved. These reagents, inter alia, may be in the form of collectors that are meant to induce the hydrophobicity of the value bearing sulfides, or they may be polymeric depressants, chosen carefully to induce the hydrophilicity of the non-sulfide gangue minerals such as chlorite, chromite, feldspar, pyroxene, and talc. Thus, reagent suites, regimes, and schemes have been developed and specifically tailored towards the management of the non-sulfide gangue for various $\mathrm{Cu}-\mathrm{Ni}$-PGM ores so as to ensure that higher concentrate grades are achieved [1]. Nevertheless, constant changes and challenges on ore mineralogy and environmental restrictions on the use of natural and scarce resources demand that further investigative work be conducted on the impact that some of these reagents will have on the sub-processes of flotation [2].

It is well known that water is a scarce resource; the low availability of fresh water nearby mining locations is one of the major threats to the success of froth flotation since water acts as both a reagent and a transport medium on the interfacial phenomena of flotation. The decreasing availability of fresh water globally is a serious threat not only to the mining industry and its sustainability but it also threatens economic growth and investment opportunities especially in countries such as South Africa whose economy is strongly impacted by the mining industry. Thus, the supply of fresh water is critical for both human consumption and industrial usage, especially in arid areas within which most mines are located. For this reason, minerals processing operations are considering plant water recirculation as a possible and more sustainable option in response to the global scarcity of fresh water. However, the use of recycled plant water in flotation may lead to an accumulation of inorganic electrolytes which may in turn alter flotation performance due to changes in the process pulp chemistry $[3,4]$.

Literature has shown that the presence of inorganic electrolytes in plant water alters the mineral surface properties in such a way that collector adsorption onto the mineral surface may be affected, thereby affecting mineral particle hydrophobicity and floatability [2,5-10]. The adsorption of the collector at the mineral-water interface can be hindered by metal ions which hydrolyse in alkaline pH solution and precipitate as hydrophilic metal hydroxides, sulfates and or carbonates [11-15]. Fundamental studies have shown that the presence of inorganic electrolytes such as thiosulfates and calcium at high concentrations can contribute to mineral dissolution, possibly increasing the attraction force between mineral particles and collector molecules, thus resulting in high solids recovery $[8,9,16-20]$. Ions such as sulfite have been found to promote the decomposition of xanthate collectors in the presence of oxygen [21]. Kirjavainen et al. [22] found that the presence of thiosulfate ions decreased the adsorption of hydrophilic compounds such as metal hydroxides at the mineral surface. Atkin et al. [23] and Subramanian and Ducker [24] reported that chloride ions had less influence on the adsorption of hexadecyl trimethyl-ammonium surfactant compared to bromide ions because of the lower binding efficiency of chloride ions compared to that of bromide ions. Xu and Boyd [25] reported that higher ionic strengths and changes of the counter-ions for $\mathrm{Cl}^{-}, \mathrm{Br}^{-}$and $\mathrm{SO}_{4}{ }^{2-}$ resulted in increased adsorption of quaternary ammonium compounds by hydrophobic bonding, therefore resulting in high mineral recoveries.

Also, it has been found that the presence of electrolytes can improve bubble-particle attachment efficiency through the compression of the electrical double layer and thereby reducing the electrostatic repulsion between bubbles and particles which in turn result in more particles reporting to the concentrate launder [8,9]. Koh et al. [26] and Schwartz and Grano [27] argued that the reduction in mineral surface hydrophobicity resulting from the precipitation of hydrophilic metal hydroxides on the mineral particle surface could compromise the efficiency of the bubble-particle attachment sub-process of flotation, and could in turn affect floatability and flotation performance. From the background and literature presented, it is evident that inorganic electrolytes which are found in plant water and their ionic strength may affect mineral recovery by altering mineral-collector adsorption. The practice of using mixtures of different collectors is widely implemented in the minerals processing industry [28-32]. Nagaraj and Ravishankar [33] submit that the use of single collectors in the flotation 
of poly-sulfide ores may not cover the full spectrum of sulfide minerals present in the ore; the use of mixed collector reagent recipes is therefore justifiable due to notable synergism and selectivity improvements that may be realised. This behaviour is however not limited to polysulfide ores only. Bradshaw et al. [29] studied the effect of mixtures of xanthate and dithiocarbamate (DTC) on pyrite flotation whilst Heilbig et al. [30] studied the effect of mixtures of xanthate and sodium di-iso-butyl dithiophosphate (DTP) on pyrite flotation; both researchers reported enhanced flotation performance in the presence of DTP. They attributed this behaviour to increased mineral hydrophobicity due to collector-collector synergistic effects. The synergistic effect of DTP with dithiocarbamate in the flotation of arsenopyrite and pyrite was studied by O'Connor et al. [34]; the results showed that improved recoveries were obtained with a mixture of the two collectors rather than with DTP alone.

The phenomenon of synergism between reagents is complicated due to the fact that reagents used in industrial plants are not always synthesized from pure products and synergism may occur inadvertently due to dissolved impurities from the collector. Therefore, the roles and interactions of individual reagents may be difficult to isolate due to the complexity of the flotation process [35]. Corin et al. [36] investigated the role of DTP as a co-collector to SIBX at fixed total molar concentrations in the flotation of a platinum group mineral ore and concluded that there was no conclusive evidence of synergism between DTP and SIBX and that the enhancement in floatability was due to DTP's froth stabilising effect owing to its effect on increasing the recovery of fines (with a particle size of $<25 \mu \mathrm{m}$ ). This could be said to have been a parallel reaction in the flotation system rather than synergism between the two thiol collectors [36]. Therefore, it is apparent that exact mechanisms of synergistic enhancement of flotation performance observed when using thiol collector mixtures are still a subject open to considerable debate and some have claimed collector-collector interactions, collector-frother interactions or even frother-frother interactions [35,36].

On the impact of collector mixtures in $\mathrm{Cu}-\mathrm{Ni}-\mathrm{PGM}$ ores, literature has shown that mixtures of collectors can result in froth flotation performance improvements such as increased grades and recoveries, increased flotation rate, and improved flotation of coarse particles; all of these achieved under lower collector dosages compared to when a single collector is used [11,14,32,36-39]. Lotter and Bradshaw [32] suggested that though mixtures of collectors do show improvements in flotation performance, the valuable-gangue composite particles may be targeted, resulting in more non-valuable solids reporting to the concentrate at the expense of the concentrate grade. However, it is not known whether the benefits reported from these thiol collector mixtures would still be realised in changing water chemistry, particularly in degrading water quality as Cu-Ni-PGM concentrators move more towards the use of recycled water and dithiophosphates for all the suggested benefits, both the positive socio-economic and environmental footprint associated with water re-use and the use of dithiophosphates compared to xanthates. Therefore, this study evaluates the effects of increasing ionic strength of plant water on the behaviour and performance of mixed thiol collectors (SIBX and SEDTP) using a Cu-Ni-Pt bearing ore from the Merensky reef.

\section{Experimental Procedure}

$1 \mathrm{~kg}$ ore samples, consisting of $\sim 1.09 \mathrm{wt} \%$ base metal sulfides (chalcopyrite, pentlandite, pyrrhotite and pyrite) with the rest ( 98.91 $\mathrm{wt} \%)$ being non-sulfide gangue minerals [5], were prepared from a bulk ore sample obtained from the Merensky reef of the Bushveld Igneous Complex of Southern Africa. These $1 \mathrm{~kg}$ ore samples were milled in an Eriez stainless steel laboratory scale rod mill with a diameter of $200 \mathrm{~mm}$. The mill was charged with twenty stainless steel rods of varying diameter in the following ratio: $6 \times 25 \mathrm{~mm}, 8 \times 20 \mathrm{~mm}$, and $6 \times 16 \mathrm{~mm}$. The $1 \mathrm{~kg}$ portions of the prepared ore samples were milled at $66 \%$ solids in synthetic plant water of a required ionic strength (Table 1 ) to achieve a grind of $60 \%$ passing $75 \mu \mathrm{m}$. The grind of $60 \%$ passing $75 \mu \mathrm{m}$ was chosen as it mimics the primary rougher grind used in operations of the selected sulfidic $\mathrm{Cu}$-Ni-PGM ore. The milling time required to achieve a grind of $60 \%$ passing $75 \mu \mathrm{m}$ was $13 \mathrm{~min} 30 \mathrm{~s}$ as shown in Figure 1 . The milled slurry was then transferred into a $3 \mathrm{~L}$ Barker batch flotation cell. The volume of the cell was made up to generate $35 \%$ solids using 
synthetic plant water (at the required ionic strength). The cell was fitted with a variable speed drive and the pulp level was controlled manually. The impeller speed was set at $1200 \mathrm{rpm}$. An air flow rate of $7 \mathrm{~L} / \mathrm{min}$ was maintained for all flotation experiments and a constant froth height of $2 \mathrm{~cm}$ was sustained throughout. The froth height was constantly corrected to $2 \mathrm{~cm}$ by the addition of synthetic plant water at the ionic strength of plant water being tested. Reagents were dosed and allowed to condition for defined times ( $1 \mathrm{~min}$ and $2 \mathrm{~min}$ for the selected frother and depressant, respectively) before flotation. Concentrates were collected at 2, 6, 12, and $20 \mathrm{~min}$ respectively by scraping the froth into concentrate trays every $15 \mathrm{~s}$. A feed sample was taken before and tails sample after each flotation test. Feeds, concentrates and tails were filtered, dried, and weighed before analysis. $\mathrm{Cu}$ and total $\mathrm{Ni}$ analyses were determined using a Bruker S4 Explorer XRF Spectrometer (S4 Explorer, Bruker South Africa (Pty) Ltd., Johannesburg, South Africa). Assuming the stoichiometries for chalcopyrite and pentlandite to be $\mathrm{CuFeS}_{2}$ and (FeNi)S respectively, the recoveries of copper and total nickel can be used to estimate the recoveries of chalcopyrite and pentlandite respectively [40].

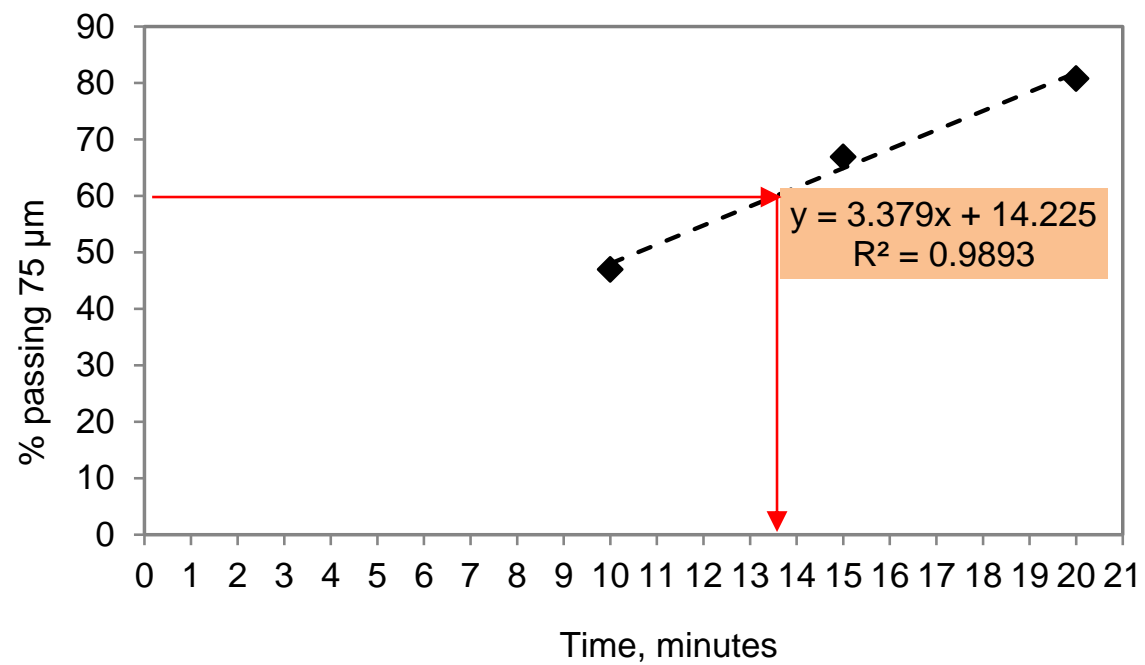

Figure 1. Milling curve for the selected Merensky ore.

A total collector dosage of $150 \mathrm{~g} / \mathrm{t}$, based on 4 selected molar ratios shown in Table 2, was used throughout the study. Collectors were supplied by Senmin, their molar masses and purities are shown in Table 3. Sodium di-ethyl dithiophosphate was chosen over other DTPs such as sodium di-isobutyl dithiophosphate so as to minimise any detrimental side effects of frothing that would confound the results [36]. DOW 200, supplied by Betachem, was used as a frother at a fixed dosage of $40 \mathrm{~g} / \mathrm{t}$. A sodium carboxymethyl cellulose (CMC) polysaccharide depressant, Depramin 267 was used throughout the study at a dosage of $100 \mathrm{~g} / \mathrm{t}$ and was not corrected for active content. The CMC, Depramin 267, was supplied by AKZO Nobel Functional Chemicals; $1 \%$ solutions were prepared for the depressant for use in the batch flotation tests by adding the required amount of CMC powder into distilled water for two hours using a Magnetic Stirrer (Hotplate-Stirrer, ChemLab Supplies, Johannesburg, South Africa) to allow complete dissolution [41]. The 1\% depressant solution was prepared fresh every third day. The properties of the depressant are shown in Table 4. Two types of synthetic plant water, namely 1SPW (typical plant water) and 5SPW (abnormal plant water) as seen in Table 1 were used. These were based on a typical plant water recipe which comprises of various electrolytes making up a total dissolved solids (TDS) of $1023 \mathrm{mg} / \mathrm{L}$ (for 1SPW) [31] with an ionic strength of $0.0242 \mathrm{~mol}^{\circ} \cdot \mathrm{dm}^{-3}$ whilst the amounts of salts were multiplied by 5 to make up 5SPW with a TDS of $5115 \mathrm{mg} / \mathrm{L}$ and an ionic strength of $0.1212 \mathrm{~mol} \cdot \mathrm{dm}^{-3}$ [5]. Though it is acknowledged that the effect of $\mathrm{pH}$ can be of significant importance, the given study did not consider $\mathrm{pH}$ variations. Thus, a $\mathrm{pH}$ of 9 was maintained throughout the test work as is common in most sulfidic Cu-Ni-PGM ore concentrators due to the non-sulfide gangue buffering capacity [41]. 
Table 1. Ion concentration in synthetic plant water (SPW).

\begin{tabular}{ccccccccccc}
\hline $\begin{array}{c}\text { Water } \\
\text { Type }\end{array}$ & $\begin{array}{c}\mathrm{Ca}^{2+} \\
(\mathbf{m g} / \mathrm{L})\end{array}$ & $\begin{array}{c}\mathbf{M g}^{2+} \\
(\mathbf{m g} / \mathbf{L})\end{array}$ & $\begin{array}{c}\mathrm{Na}^{+} \\
(\mathbf{m g} / \mathrm{L})\end{array}$ & $\begin{array}{c}\mathrm{Cl}^{-} \\
(\mathbf{m g} / \mathrm{L})\end{array}$ & $\begin{array}{c}\mathrm{SO}_{4}{ }^{2-} \\
(\mathbf{m g} / \mathrm{L})\end{array}$ & $\begin{array}{c}\mathrm{NO}_{3}{ }^{-} \\
(\mathbf{m g} / \mathrm{L})\end{array}$ & $\begin{array}{c}\mathrm{CO}_{3}{ }^{2-} \\
(\mathbf{m g} / \mathbf{L})\end{array}$ & $\begin{array}{c}\text { TDS } \\
(\mathbf{m g} / \mathrm{L})\end{array}$ & $\begin{array}{c}\mathrm{IS} \\
{[\mathbf{M}]}\end{array}$ & Class \\
\hline $1 S P W$ & 80 & 70 & 153 & 287 & 240 & 176 & 17 & 1023 & 0.0242 & Typical \\
$5 S P W$ & 400 & 350 & 765 & 1435 & 1200 & 880 & 85 & 5115 & 0.1212 & Abnormal \\
\hline
\end{tabular}

Table 2. SIBX-SEDTP recipes in \% molar ratios used for a total collector dosage of $150 \mathrm{~g} / \mathrm{t}$.

\begin{tabular}{|c|c|c|c|c|c|}
\hline \multirow{2}{*}{$\begin{array}{l}\text { Collector } \\
\text { SIBX:DTP }\end{array}$} & \multicolumn{5}{|c|}{ Molar Ratios (\%) } \\
\hline & 100:0 & $90: 10$ & $50: 50$ & $10: 90$ & $0: 100$ \\
\hline
\end{tabular}

Table 3. Characteristics of the selected thiol collectors.

\begin{tabular}{cccc}
\hline Collector Name & Abbreviation & $\mathbf{M}_{\mathbf{r}}, \mathbf{g} / \mathbf{m o l}$ & \% Purity \\
\hline Sodium iso-butyl xanthate & SIBX & 200.00 & 97 \\
Sodium di-ethyl dithiophosphate & SEDTP & 208.21 & 45 \\
\hline
\end{tabular}

Table 4. Properties of the selected sodium carboxymethyl cellulose.

\begin{tabular}{ccccc}
\hline Depressant & $\mathbf{M}_{\mathbf{r}}, \mathbf{g} / \mathbf{m o l}$ & Density, $\mathbf{g} / \mathbf{m L}$ & \% Purity & Degree of Substitution \\
\hline CMC: depramin 267 & 325,000 & 1.43 & 72 & 0.68 \\
\hline
\end{tabular}

\section{Results and Discussion}

As the aim of this investigation was to investigate the effect of thiol collector mixtures in plant water of increasing ionic strength on the recovery and grade of valuable minerals, specifically $\mathrm{Cu}$ and Ni from a Cu-Ni-PGM bearing Merensky ore, this section presents the results and discussion of this investigation.

\subsection{The Effect of Varying Thiol Collector Mixture and Ionic Strength of Plant Water on Solids and Water Recoveries}

Figure 2 shows total solids and water recoveries for all conditions tested. It is evident that both solids and water recoveries generally increased with an increase in the molar ratio of sodium di-ethyl dithiophosphate (SEDTP) under both typical plant water (1SPW) and abnormal plant water operations (5SPW). It can also be seen that for every corresponding collector condition, increases in the ionic strength of plant water resulted in increased solids and water recoveries except for SIBX 90\%: SEDTP 10\% where water recoveries decreased when operating with abnormal plant water. An increase in water recoveries with increasing ionic strength of plant water for a fixed SIBX/SEDTP mixture is in agreement with studies that showed that water and solids recoveries both increased with an increase in the ionic strength of plant water; although these were conducted in the presence of SIBX as the only collector $[16,19,40]$. The increase in water recovery at a fixed froth height and higher ionic strength of plant water is attributed to the presence of electrolytes which enhance the stability of the froth. The presence of ions commonly found in plant water such as $\mathrm{Ca}^{2+}, \mathrm{Mg}^{2+}, \mathrm{Na}^{+}$, and $\mathrm{Cl}^{-}$results in more stable froths due to a reduction in repulsive forces between minerals and bubbles, resulting in a reduction in bubble coalescence, which in turn results in increases in solids and water recoveries [42-45]. Also, an increase in solids and water recoveries in increasing SEDTP molar ratio is in agreement with Corin et al. [36] who investigated the role of SEDTP as a co-collector in the flotation of a similar Pt bearing ore. Corin et al. [36] also found that higher SEDTP dosages improved the stability of the froth. Therefore, it can be said that SEDTP and ionic strength resulted in a parallel froth stabilising effect as seen in Figure 2. SEDTP's froth stabilising effect is attributed to its residual alcohol from the manufacturing or synthesis process as can be seen in Table 1 that the purity of the sample used was $45 \%$ with the remainder being impurities mainly associated with the 
synthesis process [36]. Also, the increase in solids recoveries at higher SEDTP molar ratios could be indicative of ions disrupting the hydration layers surrounding mineral particles, where ions may have changed the surface charge of the particles and penetrated through the water structure, increasing the attraction force between particles [7]. Xanthates are known to be stronger collectors compared to dithiophosphates [46], however the presence of ions affects the performance of xanthates as ions increase the selectivity of xanthates towards the valuable minerals through changes in the mineral surface charge [8,9]. It is therefore proposed that the increase in solids recovery at high SEDTP molar ratio particularly at $100 \%$ SEDTP, results from an availability of ions such as $\mathrm{Ca}^{2+}$ and $\mathrm{Mg}^{2+}$ which are known to alter the mineral particle surface charge, allowing SEDTP molecules to adsorb on the altered mineral surface. It is well known that xanthates adsorb non-selectively on all particle sizes whereas SEDTP has the ability to adsorb onto coarser particles; this may very well be the reason for higher solids recoveries at higher SEDTP molar ratios [32,36].

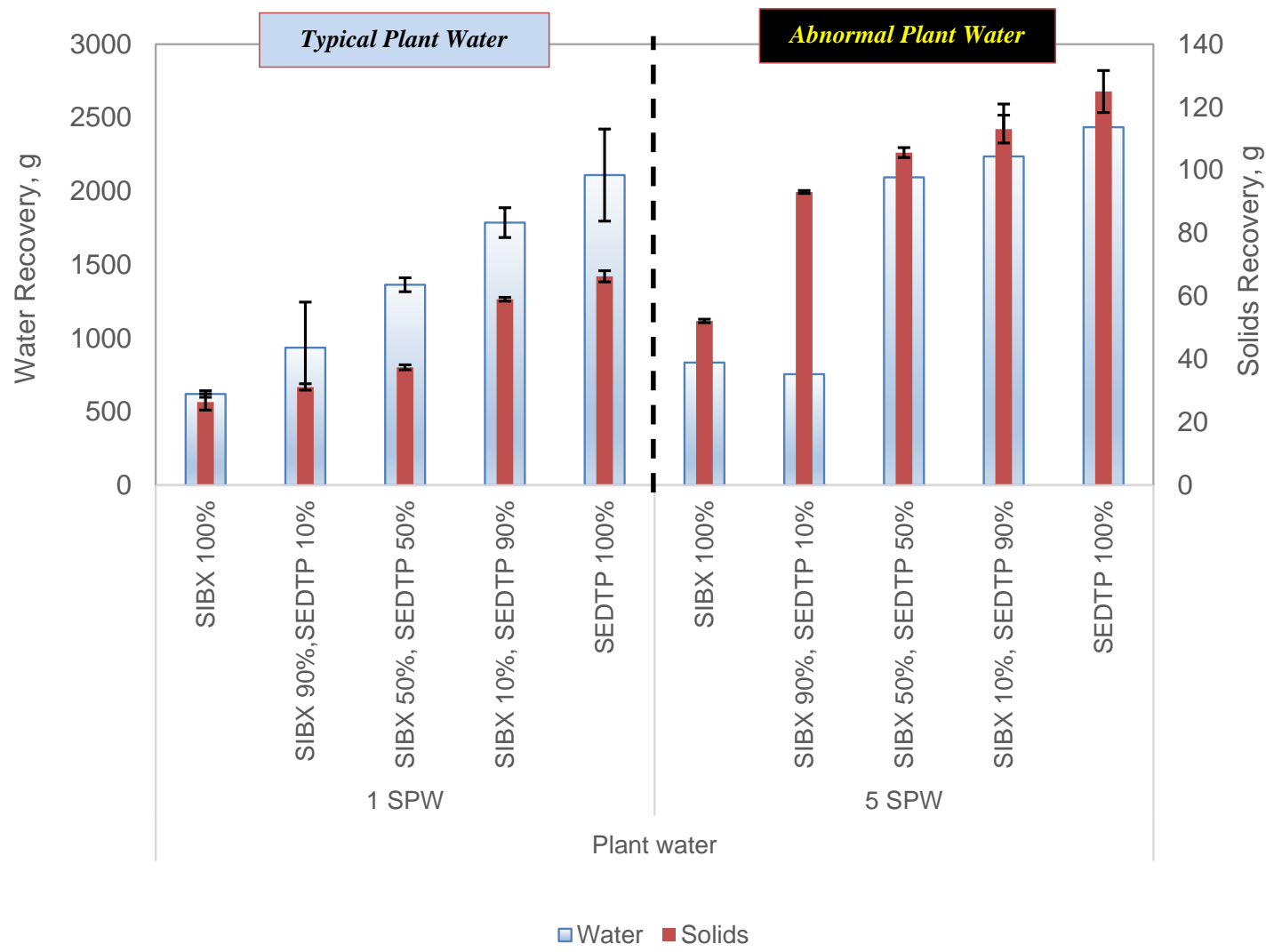

Figure 2. Water and solids recovery for all SIBX/SEDTP mixtures and ionic strengths of process water.

\subsection{The Effect of Varying Thiol Collector Mixture and Ionic Strength of Plant Water Cu and Ni Grades and Recoveries}

Figure 3 shows the total $\mathrm{Cu}$ recoveries and grades for all tested conditions. It can be seen that in both typical and abnormal plant water operations, $\mathrm{Cu}$ recoveries increased with increasing SEDTP dosage at the expense of the grade. This can be explained by the higher mass pull (Figure 2) seen in increasing SEDTP dosages which is attributed to an increase in gangue recoveries resulting from the froth stabilising effect of SEDTP. It is further illustrated that $\mathrm{Cu}$ recoveries were best at the abnormal plant water conditions (with an ionic strength of $0.1212 \mathrm{~mol} \cdot \mathrm{dm}^{-3}$ ) compared to those obtained in typical plant water (1SPW) operations. An increase in the ionic strength of plant water has been shown to increase thiol collector adsorption by reducing the repulsive forces between the anionic collector and the mineral particle, compressing the electrical double layer and thereby increasing bubble-particle attachment $[8,9]$. Figure 3 also shows that at the introduction of SEDTP $(10 \%$ thereof) in both typical 
and abnormal plant water, the grade of the concentrate with respect to $\mathrm{Cu}$ decreased. This phenomenon was more pronounced in abnormal plant water. However, higher dosages of SEDTP ( $>10 \%)$ resulted in higher $\mathrm{Cu}$ grades in abnormal plant operations (5SPW) compared to typical plant water (1SPW). It is therefore evident that there was an increase in $\mathrm{Cu}$ grade with an increase in the ionic strength of plant water (5SPW) when considering the 50:50 mixture and higher SEDTP ratios whilst the lower ionic strength of plant water (1SPW) resulted in higher grades only at higher SIBX molar ratios (with $\leq 10 \%$ SEDTP ratio).

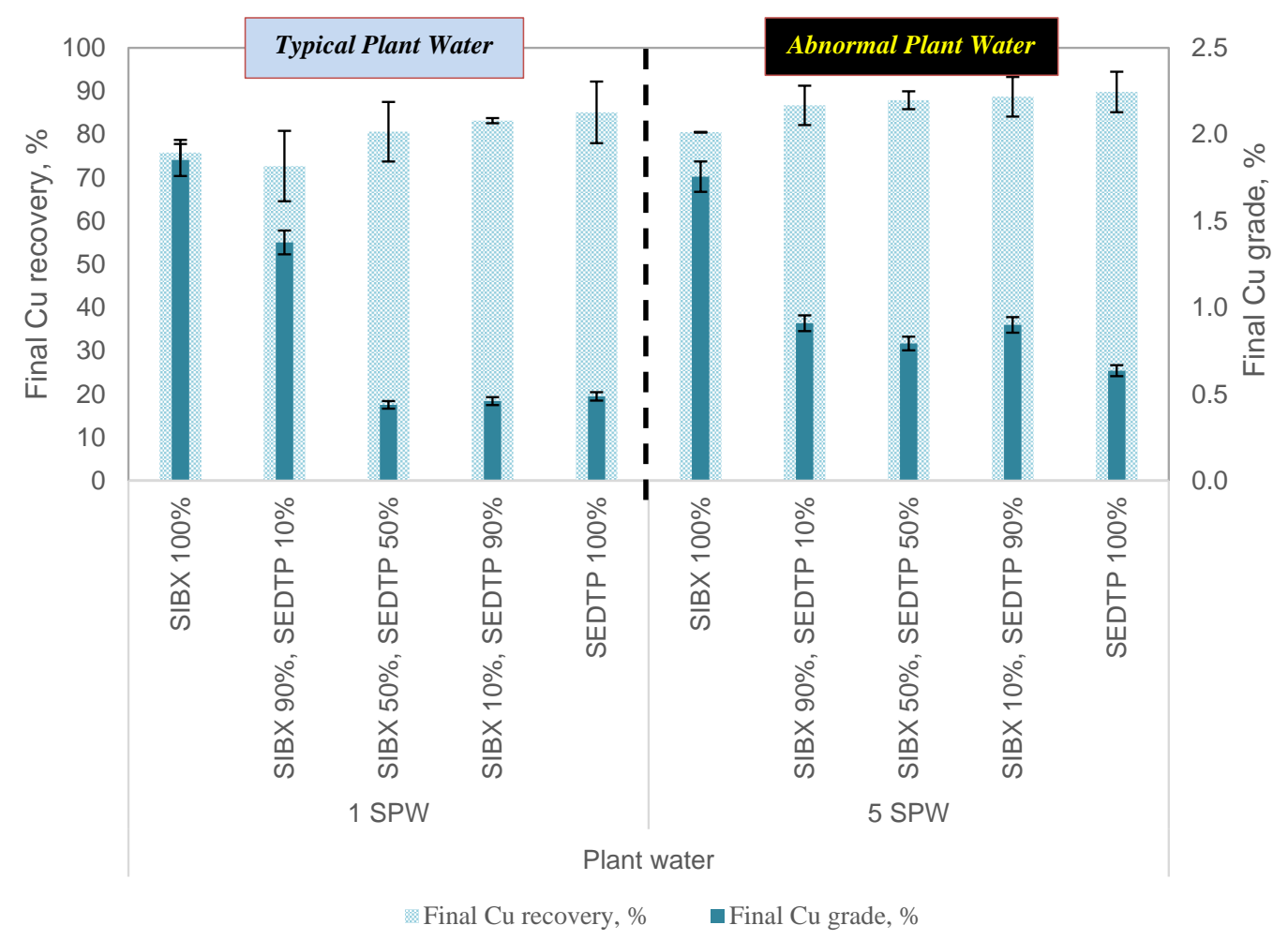

Figure 3. Final copper recoveries and grades for all SIBX/SEDTP mixtures and ionic strengths of process water.

Figure 4 shows the total Ni recoveries and grades for all thiol collector mixtures and ionic strengths of plant water. It can be seen that Ni recoveries increased with an increase in the ionic strength of plant water. Increases in SEDTP molar ratio also resulted in increased Ni recoveries. Ni grades decreased with an increase in SEDTP molar ratio at all ionic strengths of plant water. However, Ni grades were generally higher for abnormal plant water (5SPW) compared to flotation under typical plant water (1SPW).

The increase in $\mathrm{Cu}$ and Ni recoveries shown in Figures 3 and 4 at higher SEDTP molar ratio is a result of the froth stabilising effect of SEDTP which is evident from the high water recoveries seen in Figure 2. This is in agreement with studies that investigated DTP as a co-collector and plant water ionic strengths independently which showed that ionic strength of plant water and DTP dosage as independent variables affect the stability of the froth $[5,16,19,36,47]$. The increase in mineral recoveries could also be attributed to the presence of DTP, which increases the selectively of mineral adsorption and thereby increasing valuable mineral recoveries [48]. Also, the higher Ni recoveries in higher SEDTP molar ratios and abnormal plant water can be attributed to the behaviour of typical sulfidic Ni bearing Merensky ores in that pentlandite tends to exist in gangue composites such that when the pulp environment promotes froth stability and entrainment, Ni recoveries tend to increase as a result of grains that are locked in gangue composites being recovered through increases in entrainment [49]. $\mathrm{Cu}-\mathrm{Ni}$ mineral recovery trends seen in this study are in agreement with McFadzean et al. [39] who 
found that the best collector for pyrite was a 75:25 SIBX: SEDTP mixture which increased overall recoveries of pyrite to $93.4 \%$ compared to $89.8 \%$ for a system using 100 SIBX: 0 SEDTP.

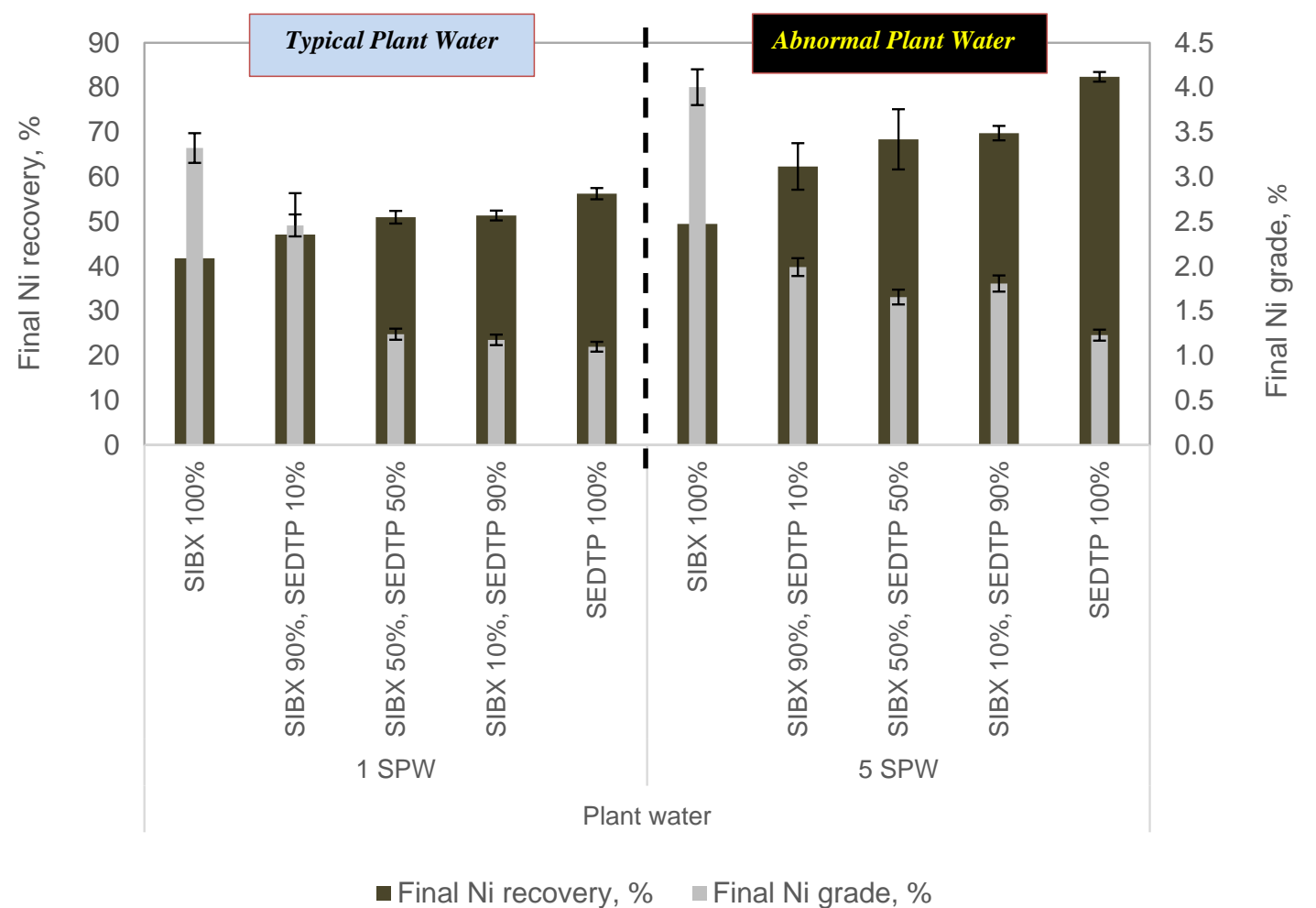

Figure 4. Final nickel recoveries and grades for all SIBX/SEDTP mixtures and ionic strengths of process water.

The decrease in $\mathrm{Cu}$ and $\mathrm{Ni}$ grades with an increase in SEDTP molar ratio at all ionic strengths of plant water is attributed to an increase in froth stability in increasing SEDTP molar ratio which resulted in more gangue reporting to the concentrate as seen in the higher solids recoveries shown in Figure 2. Figures 3 and 4 showed that at higher SIBX molar ratios ( $\leq 10 \%$ SEDTP), higher $\mathrm{Cu}$ and Ni grades were achieved. This is attributed to lower gangue recoveries and possibly lower entrainment too, as indicated by low water and solids recoveries in both typical and abnormal plant water operations. This finding is similar to that of Kloppers et al. [48] who showed that the use of pure SIBX resulted in higher $\mathrm{Cu}$ and Ni recoveries and grades as compared to DTP (4-carbon chain length) and DTC (5-carbon chain length). This indicates that the absence of DTP resulted in lower froth stability, thereby impeding the floatability and entrainment of gangue and hence higher $\mathrm{Cu}$ and $\mathrm{Ni}$ grades were achieved at higher SIBX molar ratios $(\leq 10 \%$ SEDTP). The increase in both $\mathrm{Cu}$ and Ni grades at higher SIBX molar $(\leq 10 \%$ SEDTP) ratios under abnormal plant water operations (5SPW) indicates that the presence of inorganic electrolytes at higher concentrations destabilsed the hydrated layer surrounding the mineral particle, compressing the electrical double layer which in turn resulted in an increase in the attraction forces between mineral particles and the collector ions. This phenomenon, consequently resulted in more valuable minerals being attached to air bubbles. This argument is supported by October et al. [9] who showed increases in the zeta potential of chalcopyrite in 5SPW compared to 1SPW. Such an increase in zeta potential resulted in increased SIBX adsorption, increased bubble-particle attachment and mineral recoveries.

\section{Conclusions}

The use of thiol collector mixtures has become common in the flotation of platinum bearing ores and this has proved to be beneficial in mineral recoveries and grades. However, with the change in 
process water quality, resulting from water recycling and reuse in flotation circuits, this practice and its reported benefits may be affected. Thus, an investigation of how the behaviour of thiol collector mixtures may be affected by water quality was essential. Thus, the following observations and conclusions have been made:

(1) It has been shown that solids and water recoveries increased with both an increase in SEDTP molar ratio and an increase in the ionic strength of plant water. This showed a parallel effect on froth stability, suggesting an additive interaction on the action of SEDTP and inorganic electrolytes at the air-water interface.

(2) $\mathrm{Cu}$ and $\mathrm{Ni}$ recoveries increased with an increase in SEDTP molar ratio and ionic strength of plant water owing to an increase in froth stability.

(3) Increasing SEDTP molar ratio resulted in a decrease in $\mathrm{Cu}$ and $\mathrm{Ni}$ grades owing to greater amounts of gangue reporting to the concentrate as a result of the role of SEDTP on the stability of the froth.

(4) In abnormal plant water, $\mathrm{Cu}$ and $\mathrm{Ni}$ grades were higher compared to typical plant water. This can be attributed to increases in the concentration of ions such as $\mathrm{Ca}^{2+}$ and $\mathrm{Mg}^{2+}$ which have been shown to increase the performance of CMC as a depressant for naturally floatable gangue [50].

(5) Overall, higher froth stabilities, and higher mineral recoveries and grades were obtained in abnormal plant water.

This study has shown that, when considering thiol collector mixtures and their individual action on the pulp chemistry and the consequential implications on the froth phenomena, the quality of process water is an important aspect to consider as it may alter the behaviour of DTP as a co-collector during flotation owing to ion-reagent-mineral interactions occurring in the pulp phase.

Author Contributions: Conceptualization, M.S.M., K.M., I.O.O., C.K.T., K.C.C. and J.G.W.; methodology, M.S.M. and K.M.; formal analysis, M.S.M., K.M., I.O.O.; investigation, M.S.M., K.M., I.O.O.; resources, M.S.M.; data curation, M.S.M., K.M.; writing-original draft preparation, M.S.M., K.M.; writing-review and editing, M.S.M., K.M., I.O.O., C.K.T., K.C.C. and J.G.W.; supervision, M.S.M., I.O.O., C.K.T.; project administration, M.S.M., I.O.O., C.K.T.; funding acquisition, M.S.M. All authors have read and agreed to the published version of the manuscript.

Funding: This work is based on research funded by the National Research Foundation of South Africa (NRF) (Grant no. 118062-Water Quality in Flotation: Causes, Impacts and Process Management Strategies). Any opinion, finding, and conclusion or recommendation expressed in this material is that of the authors and the NRF does not accept any liability in this regard. The APC was funded by the University of Cape Town.

Acknowledgments: The authors would like to acknowledge the Vaal University of Technology (VUT), the Center for Minerals Research (CMR) and its Reagents Research Group's members for supporting this project.

Conflicts of Interest: The authors declare no conflict of interest.

\section{References}

1. O'Connor, C.; Wiese, J.; Corin, K.; McFadzean, B. On the management of gangue minerals in the flotation of platinum group minerals. Min. Metall. Explor. 2019, 36, 55-62. [CrossRef]

2. Manono, M.; Corin, K.; Wiese, J. Perspectives from literature on the influence of inorganic electrolytes present in plant water on flotation performance. Physicochem. Probl. Miner. Process. 2018, 54, 1191-1214.

3. Moimane, T.M.; Corin, K.C.; Wiese, J.G. The effect of varying pulp reagent chemistry on the flotation performance of a South African PGM ore. Miner. Eng. 2016, 95, 155-160. [CrossRef]

4. Sheni, N.; Corin, K.; Wiese, J. Considering the effect of pulp chemistry during flotation on froth stability. Miner. Eng. 2018, 115, 15-23. [CrossRef]

5. Manono, M.; Corin, K.; Wiese, J. Water quality effects on a sulfidic PGM ore: Implications for froth stability and gangue management. Physicochem. Probl. Miner. Process. 2018, 54, 1253-1265.

6. Michaux, B.; Rudolph, M.; Reuter, M.A. Challenges in predicting the role of water chemistry in flotation through simulation with emphasis an emphasis on the influence of electrolytes. Miner. Eng. 2018, 125, 252-264. [CrossRef]

7. Hancer, M.; Celik, M.S.; Miller, J.D. The significance of interfacial water structure in soluble salt flotation systems. J. Colloid Interface Sci. 2001, 235, 150-169. [CrossRef] 
8. October, L.; Corin, K.; Schreithofer, N.; Manono, M.; Wiese, J. Water quality effects on bubble-particle attachment of pyrrhotite. Miner. Eng. 2019, 131, 230-236. [CrossRef]

9. October, L.L.; Corin, K.; Schreithofer, N.; Manono, M.; Wiese, J. Considering the Ionic Strength and pH of Process Water on Bubble-particle Attachment of Sulfide Minerals: Implications for Froth Flotation in Saline Water. In Mine Water-Technological and Ecological Challenges; Khayrulina, E., Wolkersdorfer, C.H., Polyakova, S., Bogush, A., Eds.; Perm State University: Perm, Russia, 2019; pp. 437-445.

10. Wang, B.; Peng, Y. Effect of Saline Water on Mineral Flotation. Ph.D. Thesis, Unversity of Queensland, Brisbane, Australia, 2014.

11. Ikotun, B.D.; Adams, F.V.; Ikotun, A.G. Application of three xanthates collectors on the recovery of nickel and pentlandite in a low-grade nickel sulfide ore using optimum flotation parameters. Part. Sci. Technol. 2017, 35, 462-471. [CrossRef]

12. Liu, L.; Rao, S.R.; Finch, J.A. Technical note: Laboratory study of effect of recycle water on flotation of a $\mathrm{Cu} / \mathrm{Zn}$ sulphide ore. Miner. Eng. 1993, 6, 1183-1190. [CrossRef]

13. Fuerstenau, D.W.; Herrara-Urbina, R.; McGlashan, D.W. Studies on the applicability of chelating agents as universal collectors for copper minerals. Int. J. Miner. Process. 1999, 58, 15-33. [CrossRef]

14. Özün, S.; Ergen, G. Determination of optimum parameters for flotation of galena: effect of chain length and chain structure of xanthates on flotation recovery. ACS Omega. 2019, 4, 1516-1524. [CrossRef] [PubMed]

15. Zanin, M.; Lambert, H.; du Plessis, C.A. Lime use and functionality in sulphide mineral flotation: A review. Miner. Eng. 2019, 143, 105922. [CrossRef]

16. Corin, K.C.; Wiese, J.G. Investigating froth stability: A comparative study of ionic strength and frother dosage. Miner. Eng. 2014, 66-68, 130-134. [CrossRef]

17. Dishon, M.; Zohar, O.; Sivan, U. From repulsion to attraction and back to repulsion: The effect of $\mathrm{NaCl}, \mathrm{KCl}$ and $\mathrm{CsCl}$ on the force between silica surfaces in aqueous solution. Langmuir 2009, 25, 2831-2836. [CrossRef] [PubMed]

18. Ejtemaei, M.; Plackowaski, C.; Nguyea, A.V. The effect of calcium, magnesium and sulphate ions on the surface properties of copper activated sphalerite. Miner. Eng. 2016, 89, 42-51. [CrossRef]

19. Manono, M.S.; Corin, K.C.; Wiese, J.G. An investigation into the effect of various ions and their ionic strength on the flotation performance of a platinum bearing ore from Merensky reef. Miner. Eng. 2012, 36, 231-236. [CrossRef]

20. Shengo, L.M.; Gaydardzhiev, S.; Kaleng, N.M. Assessment of water quality effects on flotation of copper-cobalt oxide ore. Miner. Eng. 2014, 65, 145-148. [CrossRef]

21. Shen, W.Z.; Fornasiero, D.; Ralston, J. The flotation of sphalerite and pyrite in the presence of sodium sulfite. Int. J. Miner. Process. 2001, 63, 17-28. [CrossRef]

22. Kirjavanein, V.; Schreithofer, N.; Heiskanen, K. Effect of calcium and thiosulfate ions on flotation selectivity of Nickel-Copper ores. Miner. Eng. 2002, 15, 1-5. [CrossRef]

23. Atkin, R.; Craig, V.S.; Wanless, E.J.; Biggs, S. The influence of chain length and electrolyte on the adsorption kinetics of cationic surfactants at the silica-aqueous solution interface. J. Colloid Interface Sci. 2003, 266, 236-244. [CrossRef]

24. Subramanian, V.; Ducker, W.A. Counter Ion effects on adsorbed miceller shape: Experimental study of the role of polarizability and charge. Langmuir 2000, 16, 4447-4454. [CrossRef]

25. Xu, S.; Boyd, S.A. Cationic surfactant sorption to a vermiculitic subsoil via hydrophobic bonding. Environ. Sci. Technol. 1995, 29, 321. [CrossRef] [PubMed]

26. Koh, P.T.L.; Hao, F.P.; Smith, L.K.; Chau, T.T.; Bruckard, W.J. The effect of particle shape and hydrophobicity in flotation. Int. J. Miner. Process. 2009, 93, 128-134. [CrossRef]

27. Schwarz, S.; Grano, S. Effect of particle hydrophobicity on particle and water transport across a flotation froth. Colloids Surf. A Physicochem. Eng. Asp. 2005, 256, 157-164. [CrossRef]

28. Taggart, A. Handbook of Mineral Processing; Wiley: New York, NY, USA, 1950.

29. Bradshaw, D.; Harris, P.; O'Connor, C. Synergistic interactions between reagents in sulphide flotation. J. South Afr. Inst. Min. Metall. 1998, 98, 189-193.

30. Heilbig, C.; Bradshaw, D.; Harris, P.; O'Connor, C.T.; Baldauf, H. The synergistic interactions of mixtures of thiol collectors in the flotation of sulphide minerals. In Proceedings of the XXI International Mineral. Processing Congress, Rome, Italy, 23-27 July 2000. 
31. Wiese, J.G.; Harris, P.; Bradshaw, D. The influence of the reagent suite in the flotation of ores from the Merensky reef. Miner. Eng. 2005, 18, 189-198. [CrossRef]

32. Lotter, N.O.; Bradshaw, D.J. The formulation and use of mixed collectors in sulphide flotation. Miner. Eng. 2010, 23, 945-951. [CrossRef]

33. Nagaraj, D.R.; Ravishankar, S.A. Flotation reagents-A critical overview from an industry perspective. In Froth Flotation: A Century of Innovation; Fuerstenau, M.C., Jameson, G.J., Yoon, R., Eds.; Society of Mining, Metallurgy, and Exploration, Inc. (SME): Littleton, CO, USA, 2007; pp. 375-413.

34. O'Connor, C.T.; Bradshaw, D.J.; Upton, A.E. The uses of dithiophosphates and dithiocarbonates for the flotation of arsenopyrite. Miner. Eng. 1990, 3, 447-459. [CrossRef]

35. Pienaar, D.; Jordaan, T.; McFadzean, B.; O'Connor, C.T. The synergistic interaction between dithiophosphate collectors and frothers at the air-water and sulphide mineral interface. Miner. Eng. 2019, 138, 125-132. [CrossRef]

36. Corin, K.C.; Bezuidenhout, J.C.; O'Connor, C.T. The role of dithiophosphate as co-collector in the flotation of platinum group mineral ore. Miner. Eng. 2012, 36-38, 100-104. [CrossRef]

37. Hangone, G.; Bradshaw, D.J.; Ekmekci, Z. Flotation of copper sulphide ore from Okiep uisng thiol collectors and thier mixtures. S. Afr. Inst. Min. Metall. 2008, 105, 199-206.

38. Maree, W.; Kloppers, L.; Hangone, G.; Oyekola, S. The effects of mixtures of potassium amyl xanthate (PAX) and isopropyl ethyl thionocarbamate (IPETC) collectors on grade and recovery in the froth flotation of a nickel sulfide ore. S. Afr. J. Chem. Eng. 2017, 24, 116-121. [CrossRef]

39. McFadzean, B.; Mhlanga, S.S.; O'Connor, C.T. The effect of thiol collector mixtures on the flotation of pyrite and galena. Miner. Eng. 2013, 50-51, 121-129. [CrossRef]

40. Corin, K.C.; Reddy, A.; Miyen, L.; Wiese, J.G.; Harris, P.J. The effect of ionic strength of plant water on valuable mineral and gangue recovery in a platinum bearing ore from Merensky reef. Miner. Eng. 2011, 24, 131-137. [CrossRef]

41. Wiese, J.G. Investigating Depressant Behaviour in the Flotation of Selected Merensky Ores. Master's Thesis, Faculty of Engineering and the Built Environment, Chemical Engineering, University of Cape Town, Cape Town, South Africa, 2009.

42. Bournival, G.; Pugh, R.J.; Ata, S. Examination of $\mathrm{NaCl}$ and $\mathrm{MIBC}$ as bubble coalescence inhibitor in relation to froth flotation. Miner. Eng. 2012, 25, 47-53. [CrossRef]

43. Craig, V.S.; Ninham, B.W.; Pashley, R.M. The effect of electrolytes on bubble coalescence in water. J. Phys. Chem. 1993, 97, 10192-10197. [CrossRef]

44. Manono, M.S.; Corin, K.C.; Wiese, J.G. The effect of ionic strength of plant water on foam stability: A 2-phase flotation study. Miner. Eng. 2013, 40, 42-47. [CrossRef]

45. Marrucci, G.; Nicodemo, L. Coalescence of gas bubbles in aqueous solutions of inorganic electrolytes. Chem. Eng. Sci. 1967, 22, 1257-1265. [CrossRef]

46. Nagaraj, D.R. The chemistry and application of chelating or complexing agents in minerals separations. In Reagents in Mineral, Technology; Somasundaran, P., Moudgil, B.M., Eds.; Marcel Dekker Inc.: New York, NY, USA, 1988; pp. 387-409.

47. Bagci, E.; Ekmekci, Z.; Bradshaw, D. Adsorption behavior of xanthate and dithiophosphinate from thiol mixture on chalcopyrite. Miner. Eng. 2007, 20, 1047-1053. [CrossRef]

48. Kloppers, L.; Maree, W.; Oyekola, O.; Hangone, G. Froth flotation of a Merensky Reef Platinum bearing ore using mixtures of SIBX with a dithiophosphate and a dithiocarbonate. Miner. Eng. 2016, 87, 54-58. [CrossRef]

49. Becker, M.; Harris, P.J.; Wiese, J.G.; Bradshaw, D.J. Mineralogical characterisation of naturally floatable gangue in Merensky reef ore flotation. Int. J. Miner. Process. 2009, 93, 246-255. [CrossRef]

50. Manono, M.; Corin, K.; Wiese, J. The effect of the ionic strength of process water on the interaction of talc and CMC: Implications of recirculated water on floatable gangue depression. Minerals 2019, 9, 231. [CrossRef]

(C) 2020 by the authors. Licensee MDPI, Basel, Switzerland. This article is an open access article distributed under the terms and conditions of the Creative Commons Attribution (CC BY) license (http://creativecommons.org/licenses/by/4.0/). 